\title{
sciendo ASSESSMENT OF THE CHANGES IN THE ECONOMY OF MUNICIPAL WASTE IN POLAND AFTER 2004
}

DOI 10.2478/ntpe-2018-0007

\author{
PhD. Eng. Joanna Zarębska \\ University of Zielona Góra, Poland \\ PhD. Eng. Iwona Żabińska \\ Silesian University of Technology, Poland \\ Doc. Ing. Helena Cierna, PhD. \\ Ing. Erika Sujova, PhD. \\ Technical University in Zvolen, Slovak Republic
}

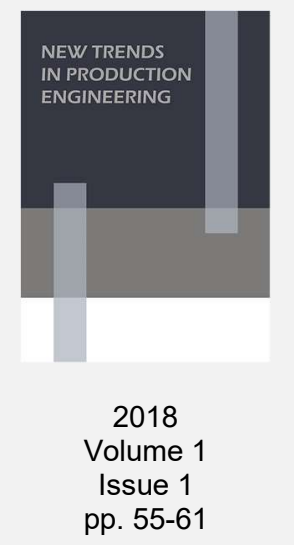

\begin{abstract}
The aim of European Union policy is to implement the principles of sustainable development, in which particularly important are: environmental protection and rational management of resources. Major role is given to waste management and appropriate prioritization of activities in this area. The main goal of waste management is prevention, minimization and elimination of wastes "at source", as well as encouraging efficient use of natural resources through recovery and recycling of waste. Storage process should be minimalized over the years until the complete elimination. As shown by statistics data, unfortunately in Poland, the process is very slow. The analysis of the data provided by the Central Statistical Office (CSO) over the last thirteen years shows a significant increase in the level of recovery and recycling of municipal waste. All together it was 11.654 million Mg of municipal waste collected in 2016. Wastes selected from municipal waste (paper, glass, plastics, metals) accounted for only $25.2 \%$ (2.942 million $\mathrm{Mg}$ ), and mixed waste accounted for $74.8 \%$ (8.712 million $\mathrm{Mg}$ ). In 2016 the recycling rate was $27.83 \%$, composting or fermentation $-16.22 \%, 19.44 \%$ of municipal wastes are subjected thermal transformation and the storage level is $36.51 \%$. Landfilling is still the most common form of municipal waste disposal.
\end{abstract}

Keywords: sustainable development, waste management, municipal waste, recovery, recycling

\section{INTRODUCTION}

To ensure effectiveness of waste management is a big problem not only in Poland and Europe, but is considered as a global problem. Every year we observed an increase in the amount of waste, caused, inter alia, improved quality of life and development of civilization and inefficient use of resources. Implementation of the European Union (EU) regulations linked to rational waste management is diverse and depends on the Member State (for example, Switzerland, Netherlands, Germany, Sweden, Belgium, Denmark - stockpiled less than 3\% of municipal waste, 18 countries - including Poland - stockpiled more than $30 \%$ of municipal waste and Latvia, Croatia, Bulgaria - more than 90\%). This fact is not bringing the EU countries closer to accomplish the idea of sustainable development and other strategies (06.Sustainable ..., 2006; EEA, 2013; COM (2011) 571; COM (2014) 398), just the opposite - away. Therefore, the European Union plans to introduce a new Directive of the European Parliament and of the Council COM (2014) 397 final, which objective is to increase the efficiency of waste management. As we read in the motion "The EU economy is currently losing significant amounts of potential recyclables that are found in waste streams" (COM (2014) 397, pp. 2-6). This problem still concerns Poland, where in 2016 more than $36.51 \%$ of municipal waste was deposited in landfills (Central Statistical Office 2017).

Despite the fact that such large amount of changes in the management of municipal waste that was observed in the last 13 years, our country still need to face many challenges in order to achieve the status, recycling society". The purpose of this article is collation, analysis and assessment of changes which have taken place on the level of: production, collection, recovery and disposal of municipal waste in Poland after 2004, in other words after joining the European Union. The data concerning the waste comes mainly from national statistical studies of Central 
Statistical Office (CSO) in Warsaw and the National Waste Management Plan (NWMP 2014) developed by the Ministry of Environment.

\section{MUNICIPAL WASTE MANAGEMENT IN POLAND}

Effective waste management should be based primarily on industrial ecology that uses circulation systems (internal recycling within the enterprise and between enterprises), developed systems (usage of recyclable materials) in plants and educated society, selective waste collection, advanced sorting, composting and biogas waste. Under the existing principles of waste management in the EU, recycling is the most desirable method of their use. It should be noted, however, that in cases where, for technological, ecological or economic reasons is not possible or reuse or recycling of waste is unreasonable, residual waste must then undergo other recovery processes (incinerated with energy recovery) and other wastes that do not meet the above requirements should be disposed (further incinerated without energy recovery, storage). It is important to dispose only waste, from which previously recyclable waste were segregated, and to store only the waste, the disposal of waste that disposal is impossible. Municipal waste is undeniable source of raw material for recycling that have a specific value (for example, per ton of colorless PET-u we can receive up to 1015 PLN, and aluminum - 4003 PLN). Municipal waste in Poland contains significant amounts of recyclable materials that can be recycled as well as high-energy fraction usable as an alternative fuel component (Cheng and Hu, 2010; Kotharia et al., 2010; Michniewska, 2017; Prawisudha et al., 2012; Rosik-Dulewska, 2015; Usón et al., 2013; Zarębska, 2013; Zarębska, 2014).

To reduce the amount of waste deposited in landfills and at the same time increase the recovery and recycling level of secondary raw materials, legislation in Poland is continuously adapted to the changes in EU directives, as well as internal changes would result from the modification of related legal acts. Existing requirements for waste management, recovery and recycling of waste are determined in numerous legal regulations, including:

- the act of Environmental Protection Law (unified text Journal of Laws, 2017, pos. 519),

- the act on maintaining the cleanliness and order in communes (unified text Journal of Laws, 2017, pos. 1289),

- the law on obligations in the field of management of certain wastes and on product fee (unified text Journal of Laws, 2014, pos. 1413),

- the act on waste (Journal of Laws, 2018, pos. 21),

- the act on the management of packaging and packaging waste (Journal of Laws, 2013, pos. 888).

According to CSO data, in Poland in 2016, the amount of generated municipal waste was 11.654 million $\mathrm{Mg}$, which accounted for about $8.3 \%$ of all generated waste. The level of generated municipal waste for many years reached the size of 11 million Mg/year (for example, in 2014 it amounted to 12.08 million $\mathrm{Mg}$, in 2010 - 12.04 million $\mathrm{Mg}$, and in $2005-12.17$ million $\mathrm{Mg}$ ). Selected wastes from municipal one (i.e. paper, glass, plastics, metals and others) accounted for only $25.25 \%$ (2.942 million $\mathrm{Mg}$, of which: 2,621 $\mathrm{mln} \mathrm{Mg}$ have been collected from households), and mixed waste accounted for $74.75 \%$ (8.712 million Mg, of which $6.943 \mathrm{mln} \mathrm{Mg}$ have been collected from households, $0.268 \mathrm{mln} \mathrm{Mg}$ from public utilities, $1.501 \mathrm{mln} \mathrm{Mg} \mathrm{-} \mathrm{from}$ trade, small business and offices) (CSO, 2017).

Since the Poland's entrance into the European Union structures, so since 2004, it was observed a successive increase in the participation of selected wastes from mixed waste and selected from the stream of collected municipal waste and a decrease in waste sent to landfill. Summary statistics from the years 2004-2016 of the mass of recycled or disposed municipal waste in Poland are presented in Table 1 and Figure 1.

Analyze of data from the past 13 years, summarized in Table 1, clearly shows that the mass of municipal waste recovered and subjected to recycling is 13 times higher in comparison to 2004 year. In 2004, 249 thousand Mg of waste were recycled, and in 2016 - 3244 thousand Mg. In 2016, 1890 thousand Mg of waste were subjected to composting or fermentation (more than 8- 
times increase), thermal transformation 2260 thousand $\mathrm{Mg}$ waste (nearly 26-times increase), landfilling -4255 thousand (a decrease of 53\% compared to 2004).

Table 1.

Summary statistics from the years 2004-2016 of the mass of recycled or disposed municipal waste in Poland

\begin{tabular}{|c|c|c|c|c|c|c|c|c|c|}
\hline \multicolumn{10}{|c|}{ Collected mass of municipal waste subjected to recycling or disposal } \\
\hline Specification & Unit & Year & 2004 & 2006 & 2008 & 2010 & 2012 & 2014 & 2016 \\
\hline \multirow{2}{*}{ Recycling } & \multicolumn{2}{|c|}{ thous. Mg } & 249 & 484 & 896 & 1779 & 1240 & 2180 & 3244 \\
\hline & \multicolumn{2}{|c|}{$\%$} & 2.55 & 4.90 & 8.93 & 17.72 & 12.95 & 21.10 & 27.83 \\
\hline \multirow{2}{*}{$\begin{array}{l}\text { Composting or } \\
\text { fermentation }\end{array}$} & \multicolumn{2}{|c|}{ thous. Mq } & 234 & 358 & 385 & 790 & 1128 & 1154 & 1890 \\
\hline & \multicolumn{2}{|c|}{$\%$} & 2.40 & 3.62 & 3.83 & 7.87 & 11.78 & 11.17 & 16.22 \\
\hline \multirow{2}{*}{ Incineration } & \multicolumn{2}{|c|}{ thous. Mg } & 87 & 45 & 63 & 102 & 51 & 1560 & 2260 \\
\hline & \multicolumn{2}{|c|}{$\%$} & 0.89 & 0.46 & 0.63 & 1.01 & 0.53 & 15.10 & 19.44 \\
\hline \multirow{2}{*}{ Landfilling } & \multicolumn{2}{|c|}{ thous. Mg } & 9193 & 8987 & 8693 & 7369 & 7159 & 5437 & 4255 \\
\hline & \multicolumn{2}{|c|}{$\%$} & 94.16 & 91.02 & 86.61 & 73.40 & 74.74 & 52.63 & 36.51 \\
\hline \multirow{2}{*}{ Total } & Counted & $\begin{array}{c}\text { thous. } \\
\text { Mg }\end{array}$ & 9763 & 9874 & 10037 & 10040 & 9578 & 10331 & 11655 \\
\hline & CsO & $\begin{array}{c}\text { thous. } \\
\text { Mg }\end{array}$ & 9760 & 9877 & 10037 & 10044 & 9581 & 10330 & 11654 \\
\hline
\end{tabular}

Source: Author's own research based on (CSO, 2008 - CSO, 2017).

Increase amount of urban waste, which are subjected to recycling processes, composting and incineration is a phenomenon analogous with the "waste managing hierarchy" according to EU directives and brings Poland closer with a small step to a "recycling society". The decrease in the mass storage of municipal waste in this case means increased use of recycled materials. Changes in the management of municipal waste is shown in Figure 1, which graphically summarizes the data of recycled or disposed collected municipal waste in Poland. Differences in annual data calculated from the summary in Table 1, and the CSO data arise from the fact rounding to 1 thousand $\mathrm{Mg}$ results obtained as collected waste in individual provinces. These differences do not pose a substantial barrier in the correct description of the scale of this phenomenon.

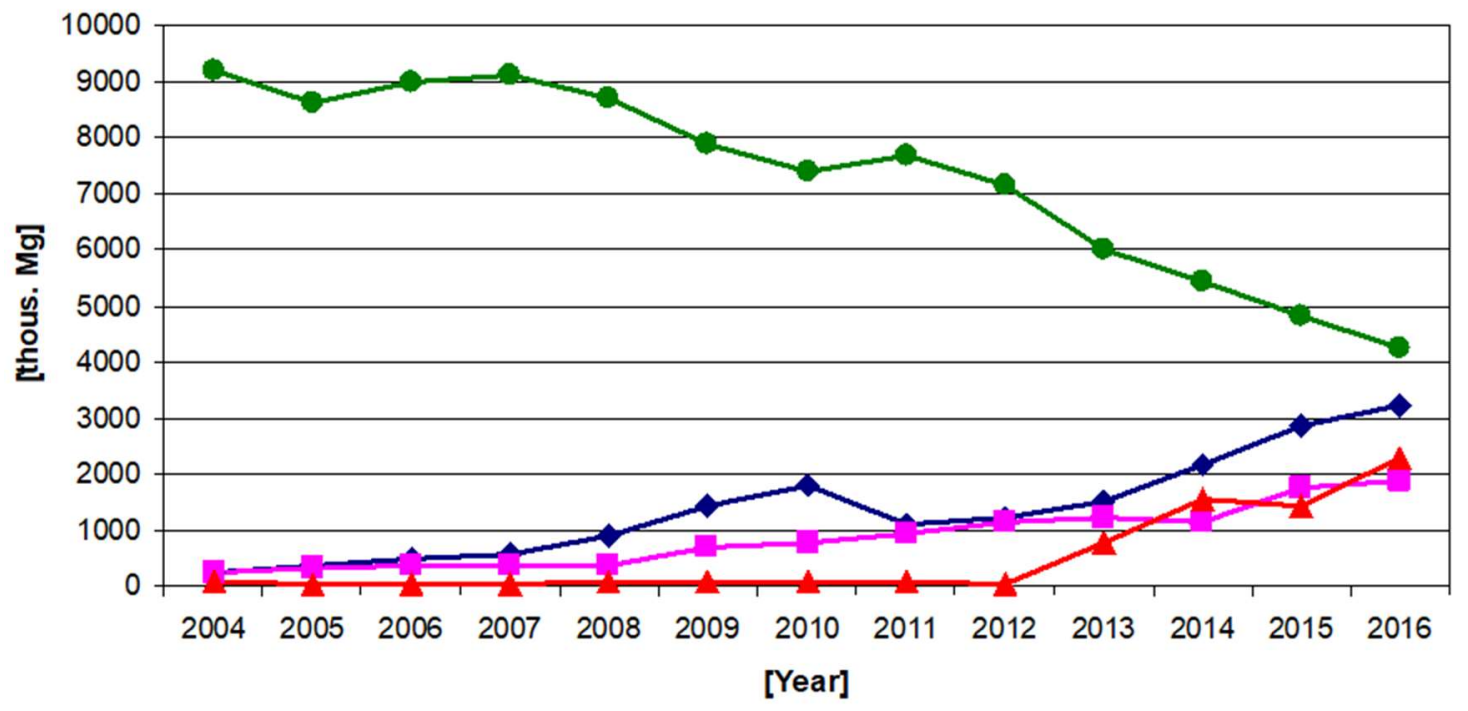

$\multimap$ Recycling $\multimap-$ Composting or fermentation $\multimap$ Incineration $\multimap-$ Landfilling

Fig. 1. Graphical comparison of statistical data on the weight of collected municipal waste in Poland subjected to recovery or disposal Source: Author's own research based on (CSO, 2008 - CSO, 2017).

Over $90 \%$ of the Polish population is covered by organized collection of municipal waste (since $2013100 \%$ of the population is covered according to CSO) but in this area there are large 
differences in the provinces and regions that affect the mass of waste collected both in the urban and rural areas. Municipal waste generated and collected in Poland in 2016 year summarized divided into provinces and regions illustrated in Table 2 (also presented in brackets is the amount of waste in kg per capita).

Table 2.

Municipal waste generated in Poland in 2016

\begin{tabular}{|c|c|c|c|c|c|c|}
\hline \multirow{2}{*}{ No. } & \multirow{2}{*}{ Province } & \multirow{2}{*}{$\begin{array}{l}\text { Region by } \\
\text { CSO }\end{array}$} & \multicolumn{2}{|c|}{ Population [thousands] } & \multicolumn{2}{|c|}{$\begin{array}{c}\text { Amount of generated municipal } \\
\text { waste [thousands of tones] }\end{array}$} \\
\hline & & & For province & $\begin{array}{l}\text { For } \\
\text { region }\end{array}$ & For province & For region \\
\hline 1 & Łódzkie & \multirow{2}{*}{ central } & 2494 & \multirow[b]{2}{*}{7843} & $685(275)$ & \multirow[b]{2}{*}{$2444(312)$} \\
\hline 2 & Mazowieckie & & 5349 & & $1759(328)$ & \\
\hline 3 & Małopolskie & \multirow{2}{*}{ southern } & 3373 & \multirow[b]{2}{*}{7944} & $975(289)$ & \multirow[b]{2}{*}{$2593(326)$} \\
\hline 4 & Śląskie & & 4571 & & $1618(355)$ & \\
\hline 5 & Lubelskie & \multirow{4}{*}{ eastern } & 2140 & \multirow{4}{*}{6714} & $419(196)$ & \multirow{4}{*}{$1387(206)$} \\
\hline 6 & Podkarpackie & & 2128 & & $446(210)$ & \\
\hline 7 & Podlaskie & & 1189 & & $291(245)$ & \\
\hline 8 & Świętokrzyskie & & 1257 & & $231(184)$ & \\
\hline 9 & Lubuskie & \multirow{3}{*}{ northwestern } & 1018 & \multirow{3}{*}{6203} & $352(346)$ & \multirow{3}{*}{$2090(337)$} \\
\hline 10 & Wielkopolskie & & 3475 & & $1132(326)$ & \\
\hline 11 & Zachodniopomorskie & & 1710 & & $606(355)$ & \\
\hline 12 & Dolnośląskie & \multirow{2}{*}{ southwest } & 2904 & \multirow{2}{*}{3900} & $1049(361)$ & \multirow{2}{*}{$1344(345)$} \\
\hline 13 & Opolskie & & 996 & & $295(296)$ & \\
\hline 14 & Kujawsko-pomorskie & \multirow{3}{*}{ nothern } & 2086 & \multirow{3}{*}{5834} & $599(288)$ & \multirow{3}{*}{$1794(307)$} \\
\hline 15 & $\begin{array}{l}\text { Warmińsko- } \\
\text { mazurskie }\end{array}$ & & 1440 & & $434(302)$ & \\
\hline 16 & Pomorskie & & 2308 & & $761(329)$ & \\
\hline \multicolumn{3}{|c|}{ Total } & \multicolumn{2}{|c|}{38437} & \multicolumn{2}{|c|}{$11654(303)$} \\
\hline
\end{tabular}

CSO - Central Statistical Office, Warsaw, Poland; (also presented in brackets is the amount of waste in $\mathrm{kg}$ per capita);

Source: Author's own research based on (CSO, 2017).

Although the European Union countries produce an average of $492 \mathrm{~kg}$ of municipal waste per capita per year (in 2015 - $483 \mathrm{~kg}$; in $2011-500 \mathrm{~kg}$ ), while in Poland this rate was in 2016, just $303 \mathrm{~kg}$ (in $2015-283 \mathrm{~kg}$; in $2011-315 \mathrm{~kg}$ ) and is among the lowest in the EU, unfortunately recovery and recycling indicators of packaging waste are at average levels compared to other EU countries and do not always fit in the standards required by the EU (in 2016 the recovery of packaging waste amounted to $61.4 \%$, recycling $-57.5 \%$, and in accordance with Directive packing should be: recovery - at least $60 \%$, overall recycling - 55-80\%) (CSO, 2017).

The European Union is constantly striving for improvement of waste management system in the community. The new European Commission's plans assume continuation of: improving the products and changing consumption patterns, production efficiency improvement, converting waste into resources, supporting research and innovation in the pursuit of resource-efficient society (COM (2011) 571). These changes, however, are not the end, because Directive COM (2014) 397 assumes raising standards for the level of recovery and recycling of packaging waste every five years which presents Table 3 .

Comparing the old plans for achieving certain levels of recycling of packaging waste (NWMP, 2010) to the new (NWMP, 2014), it is clear that raising levels of recycling of packaging waste and preparation for re-use (Journal of Laws, 2013), in Poland, will result in even greater difficulties than ever in the implementation of these objectives of packaging waste management. According to Korzeniowski and ohers (Korzeniowski et al., 2001), in Poland, the amount of packaging waste in the waste mass is estimated to be about $30 \%$ by weight and $50 \%$ by volume. 
Table 3.

Comparison of Polish and EU's legislation in terms of planned levels of recycling of packaging wastes

\begin{tabular}{|c|c|c|c|c|c|c|c|}
\hline \multirow[t]{4}{*}{$\begin{array}{l}\text { Type of packaging } \\
\text { material }\end{array}$} & \multicolumn{7}{|c|}{$\begin{array}{c}\text { Recycling and preparation level to reuse of packaging waste till } \\
\text { end of the year [in \%] }\end{array}$} \\
\hline & 2014 & 2020 & 2018 & 2020 & 2020 & 2025 & 2030 \\
\hline & \multicolumn{4}{|c|}{ national legislation } & \multicolumn{3}{|c|}{ COM(2014) 397} \\
\hline & \multicolumn{2}{|c|}{ old } & \multicolumn{2}{|c|}{$\begin{array}{c}\text { new (Journal of Laws } \\
\text { 2012) }\end{array}$} & & & \\
\hline Paper and cardboard & 60 & 61 & 30 & 50 & 85 & 90 & 90 \\
\hline Plastic & 22.5 & 23.5 & 30 & 50 & 45 & 60 & 60 \\
\hline Glass & 60 & 61 & 30 & 50 & 70 & 80 & 90 \\
\hline Ferrous metals & 50 & 51 & \multirow[t]{2}{*}{$30^{2)}$} & \multirow[t]{2}{*}{$50^{2)}$} & 70 & 80 & 90 \\
\hline Aluminum & 50 & 51 & & & 70 & 80 & 90 \\
\hline Wood & 15 & 16 & - & - & 50 & 65 & 80 \\
\hline Multimaterial| $^{3)}$ & 25 & - & 40 & 61 & \multicolumn{3}{|c|}{$\begin{array}{l}\text { By the dominant } \\
\text { material }\end{array}$} \\
\hline Total & $55-80$ & 56 & - & - & 60 & 70 & 80 \\
\hline
\end{tabular}

1) Levels are calculated together for all of the specified fraction of municipal waste. 2) Metal in general. 3) For multimaterial packaging recycling rate is the same regardless of the dominant material (Art. 25 paragraph 1 of the Act on packaging and packaging waste).

Source: Author's own research based on study based on (NWMP, 2010; NWMP, 2014; Journal of Laws, 2012 , pos. 645; Journal of Laws, 2013, pos. 888; COM (2014) 397).

Despite system of separate waste "at source" (regarded as a place where it is produced) has been functioning for a long time, the effectiveness of recovery of packaging waste from municipal waste is still low and needs to be supported by the recovery of mixed municipal waste (Zarębska, 2012; Rosik-Dulewska, 2015). Moreover, according to Grzegorz Hoppe, „Despite people segregate the waste, but they do it in such a way that, there is $70 \%$ of impurities in the waste selectively collected. This situation means that there has been no real increase in recovery of raw materials such as paper, plastics or glass". The economic factor is very important here. The prices for secondary raw materials in the last year have dropped significantly, which is also not conducive to effective collection and segregation of waste, and so: plastic packaging waste in 2013 cost an average of 1015 PLN - in 2014 the price dropped to 896 PLN; packaging waste from paper and cardboard cost 353 PLN (in 2014 the price dropped to 325 PLN; in $2016-348$ PLN); aluminum packaging waste cost 4003 PLN (in 2014 the price dropped to 3690 PLN; 2016 - 3502 PLN); glass packaging waste cost 104 PLN (in 2014 the price dropped to 45 PLN; 2016 - 47 PLN). (Michniewska, 2017).

According to Eurostat data and EEA Report, in Germany and Belgium almost $100 \%$ of the citizens segregates municipal waste, similarly like in het countries: the Czech Republic - 76\%, Slovakia - 63\%, while in Poland indicator of recycling is only $27,83 \%$ (Eurostat 2013; EEA Report, 2013). Changes in the system of municipal waste management (including packaging) introduced on 1 June 2013 slowly bring results in terms of recovery and recycling of waste, but to catch up with countries like Germany, Belgium and the Netherlands (recycling over $70 \%$ ), we should greatly increase the effectiveness of this system. Wastes collected as part of separate collection of waste should drift to the modern automated sorting plant where it will be separated by kind and, in the case of glass or plastic also selected by colors. Various recyclable materials separated in sorting department meet the requirements of customers could be assigned to the glassworks, metal smelters, paper and plastics processing plants. A well-functioning waste management system still requires significant funding, and above all, increase the flow of information (communication) between governments and local communities and greater environmental education and responsibility of producers for goods and their packaging.

\section{SUMMARY}

In assessing the changes that have occurred in the level: generation, collection, recovery and disposal of municipal waste in Poland after 2004, we can conclude that a functioning waste management system brings positive results. The level of municipal waste generation has stabilized in recent years at the level of 11-12 million Mg/year, more and more waste is collected and recovered. However, less waste is becoming deposited in landfills. Unfortunately, the tempo of these changes is too small in relation to trends and requirements demanded by the European 
Community. The Directive $\operatorname{COM(2014)~} 397$ require from Poland higher efficiency level of municipal waste management system and better results of recycling and preparation to reuse. Increasing the efficiency of waste management is possible by creating a system of closed-circuit economy. This is possible by:

- the inclusion of entrepreneurs in the actual responsibility for packaging,

- assurance of economic efficiency of waste collection and segregation,

- limitation the storage of packaging waste,

- development and promotion of the selective waste collection at "source",

- implementation of a credible monitoring system,

- implementation of information and education in broader scope,

- effective elimination of pathology and illegal activities from the market.

The closed-loop economy let added value to maintain as long as possible and eliminate waste products. They preserve resources within the economy, when product life cycle comes to an end, allowing to reuse them again in a productive manner, and thereby creating further value (COM (2014) 398, p. 2). Transition to an economy with a more closed-circuit requires from national system the changes in the value chain, from product design phase for new business models and market of new ways to transform waste (recyclables) in resources for green consumer behavior.

\section{REFERENCES}

Central Statistical Office (CSO). (2008). Environment 2008, (in Polish), Warsaw.

Central Statistical Office (CSO). (2010). Environment 2010, (in Polish), Warsaw.

Central Statistical Office (CSO). (2014). Environment 2014, (in Polish), Warsaw.

Central Statistical Office (CSO). (2017). Environment 2017, (in Polish), Warsaw.

Cheng, H., Hu, Y. (2010). Municipal solid waste (MSW) as a renewable source of energy: Current and future practices in China, Bioresource Technology, 101(11), pp. 3816-3824.

COM. (2011). 571 final. Roadmap to a Resource Efficient Europe, Communication from the Commission to the European Parliament, the Council, the European Economic and Social Committee and the Committee of the Regions. Brussels: European Commission.

COM. (2014). 397 final. Directive of the European Parliament and of the Council amending Directives 2008/98/EC on waste, 94/62/EC on packaging and packaging waste, 1999/31/EC on the landfill of waste, 2000/53/EC on end-of-life vehicles, 2006/66/EC on batteries and accumulators and waste batteries and accumulators, and 2012/19/EU on waste electrical and electronic equipment. Brussels: European Commission.

COM. (2014). 398, Towards a circular economy: A zero waste programme for Europe, Communication from the Commission to the European Parliament, the Council, the European Economic and Social Committee and the Committee of the Regions. Brussels: European Commission.

EEA Report No 2/2013. (2013). Managing municipal solid waste - a review of achievements in 32 European countries, [online] Available at: http://www.eea.europa.eu/publications/managing-municipal-solid-waste [Accessed: 08 Apr. 2015].

Eurostat. (2013). Official Website. [online] Available at: http://ec.europa.eu/eurostat/statisticsexplained/index.php/Municipal_waste_statistics [Accessed: 08 Apr 2017]

Korzeniowski, A., Skrzypek, M. and Szyszka, G. (2001). Packaging in logistic systems, (in Polish). Poznań: Library Logistics.

Kotharia, R., Tyagib, V.V, Pathakb, A. (2010). Waste-to-energy: A way from renewable energy sources to sustainable development, Renewable and Sustainable Energy Reviews, 14(9), pp. 3164-3170.

Michniewska, K. (2017). Analysis of secondary raw material prices in Poland in 2016, (in Polish). Logistyka Odzysku 1/2017(22), pp. 58-65.

Prawisudha, P., Namioka, T., Yoshikawa, K. (2012). Coal alternative fuel production from municipal solid wastes employing hydrothermal treatment, Applied Energy, 90(1), pp. 298304.

Rosik-Dulewska, Cz. (2015). Basics of waste management, $6^{\text {th }}$ ed., (in Polish). Warsaw: PWN.

The Act of 13 June 2013. on the management of packaging and packaging waste (Journal of Laws 2013, pos. 888), (in Polish), Warsaw. 
The Act of 11 May 2001, The law obligations in the field of management of certain wastes and on product fee (unified text Journal of Laws 2014, pos. 1413), (in Polish), Warsaw.

Usón, AA., López-Sabirón, AM., Ferreira, G. (2013). Uses of alternative fuels and raw materials in the cement industry as sustainable waste management options, Renewable and Sustainable Energy Reviews, 23, pp. 242-260.

Zarębska, J. (2012). Evaluation of waste packaging management system in Lubuskie. In: W. Biały and J. Kaźmierczak, eds., Systems supporting production engineering, (in Polish. Gliwice: Publisher PKJS, pp. 267-278.

Zarębska, J. (2013). Environmental and economic aspects of packaging waste management in Lubuskie, (in Polish). Zielona Góra: Publishing House of the University of Zielona Góra.

Zarębska, J. (2014). Packaging waste in Poland - current status and perspective. Management, 18(2), pp. 160-174.

06.Sustainable consumption and production, (2006), (in Polish), [online] Available at: www.eea.europa.eu/pl/publications/srodowisko-europy.pdf, [Accessed: 20 Feb. 2015].

Date of submission of the article to the Editor: 06/2018

Date of acceptance of the article by the Editor: 09/2018 